\title{
Application of Balsa Composite in Curved Structures and Its Business Establishment: A Feasibility Study
}

\section{Qori Aina1, Nadiya Rahmah², and Sri Herliana1}

${ }^{1}$ School of Business and Management, Bandung Institute of Technology

${ }^{2}$ Independent Researcher, Diyfab Colab \& Workshop, Bandung

\section{Abstract}

Balsa wood (Ochroma pyramidalei) are widely available in Indonesian market especially in the creative industry. Balsa wood was preferred due to its excellent strength to weight ratio in-line with workability and the simplicity of its color and texture. Balsa composite has increased the economic value of balsa wood and widen its use from merely lightweights and non-structural objects to some efficient super-structures. The development

Corresponding Author:

Qori Aina

aina.qorri@itb.ac.id

Received: 18 January 2019 Accepted: 24 March 2019 Published: 31 March 2019

Publishing services provided by Knowledge E

(c) Qori Aina et al. This article is distributed under the terms of the Creative Commons

Attribution License, which permits unrestricted use and redistribution provided that the original author and source are credited.

Selection and Peer-review under the responsibility of the First ELEHIC Conference Committee. of balsa composite into curved structure add another level of design sophistication and widen the variation of its use. Application of this material in a shell structure allowed the structure to have more strength to weight excellence, since the shell structure itself had already had excellent depth to span ratio. The added value of the application in Indonesia is expected to add significant contribution in national agroforestry and construction sector. However, introducing the material into construction industry required further examination, especially related to the stability of supplies (forestry management), manufacture readiness, and human resources. This paper showed a theoretical and statistical feasibility study of manufacture-scale business establishment in Indonesia.

Keywords: balsa, engineered wood, manufacture, composite, feasibility study.

\section{Introduction}

\subsection{Wood in the present market}

Indonesian forests are known to have abundant natural sources (rainwater, sunlight, and nutrition), wide varieties of wood, and-unfortunately - controversial exploitation as well. High-quality wood species such as Ulin or Iron Wood (Schleichera oleosa) and Tembesu (Frahraea fragrans), in spite of its ideal strength and durability for vernacular construction in Kalimantan and Sumatera [1-5], were no longer used in contemporary construc- 
$54 / \mathrm{Kpts} / \mathrm{Um} / 2 / 1972)$. Shifting from the highest quality, current industry in Indonesia was dominated by Acacia (Acacia mangium), Sengon (Albizzia falcate), Meranti (Shorea leprosula), Eucalyptus (Eucalyptus sp.), Merbau (Intsia spp.), Teak (Tectona grandis), Pine (Pinus merkusi), Rubber (Hevea brasilliensis), and Mahogany (Sweitenia mahagoni) [6]. These woods are relatively lower in quality than Trembesu and Ulin, but faster to grow.

\subsection{Balsa in Indonesia}

Balsa (Ochroma pyramidalei) was not originally used by Indonesian ancestor in their buildings. Balsa was introduced supposedly from Latin America [7] where Ecuador is nowadays one of the major balsa suppliers. However, due to its weight to strength excellence, Balsa had been used in Indonesia as well as other countries as raw material for boats, planes, insulation, and crafts [7-9]. Balsa could be harvested within the cycle of 5 years [7], or 6-8 years in Ecuador [9]; faster than many other popular woods in Indonesia. The popularity of balsa in Indonesia had not been overlooked by investors in agriculture and forestry sector. As the result, balsa could be easily found in Indonesian market with relatively low price.

Balsa strength to weight excellence, complemented with its light color, the workability, the simplicity of the texture, and its smooth surface, had made Balsa been so sought after as main material in many industries. Balsa development into sandwich composite and hollow-core composite had added more strength to the wood, so that it can be used as structural material $[8,10]$.

Natural condition of Indonesia and investor interest towards balsa plantation in Indonesia, suggest that Indonesia has a high prospect of being one of the major rawbalsa suppliers. However, the national economy will benefit more if the material is developed and sold with added value. This paper aims to inform the potential of balsa composite in a curved surface, and the feasibility of establishing the secondary sector balsa-composite business in Indonesia.

\section{Balsa Composite in Curved Surface}

\subsection{Curved surface}

A psychological experiment conducted by Bar \& Neta [11] showed that there is a preference for curved objects in human perception. The participants of the experiment were fourteen subjects within the age-range of 18 and 40 years old. They were given stimuli 
of 140 pairs of real object and told to quickly choose which object that they liked better from the two given pictures. The result was that curved objects were liked more than objects with a straight line or sharp angles [11]. This finding also in line with the idea of Biophilic Design, firstly introduced by Cramer \& Browning [12], an understanding of the deep-seated need of humans to connect with nature and how to incorporate them in the design. The idea of biophilia explain why a view to nature could enhance creativity and why crackling fire captivates human. Curves are common in nature, on the contrary perfect straight lines are seldom found. Hence, in order to design as close to natural condition of the world as possible, curved objects and curved surface are worth for experimental effort, scientific research, and development.

\subsection{Curve, laminate, composite, and shell structure}

There are several ways to construct a curved surface. According to Iwamoto [13], the methods are sectioning, tessellation (or tiling), folding, contouring (or carving), and forming (or molding). Sectioning, tessellation, contouring, and forming are rather straightforward. Folding, on the other hand, could be considered as an indirect way to construct a curved surface. Folding method, as in origami is about straight lines and angles. However, folding can also form a curved structure in the big picture, or create a structural support for the curved finishing surface.

The idea of curved surface is a key in shell structure development. Shell structure itself was inspired by an egg shell, a curved surface with relatively thin surface compared to its span. In civil and architectural research, there are many ways to develop shell structure: (1) single continuous plate [14], (2) folded plate [15], (3) lamella structure [14], (4) wrapped surface [14], (5) grid shell structure [14, 16], and (6) ribbed or framed structure [14]. All of these methods are also creating a curved surface. Both shell structure and curved surface works in three directional axis. In a shell structure, the surface should be able to distribute load and forces evenly to three dimensional direction so that all surface area could endure the same forces.

In the construction point of view, the method of creating a curved surface can be divided based on the material used: (1) bricks, (2) frame (steel frame, timber frame), (3) shingles, (4) membrane, and (5) in situ casting. Wood material such as balsa could be used effectively as frame and shingles. If balsa shingles are laminated into curved surface, hypothetically the final structure can distribute loads and forces in a similar way of a single continuous plate. However, balsa in raw form is inadequate for a structural project. Reinforcing balsa with fiber $[8,17,18]$ and impregnating balsawith nanoparticle 
[19] are two exemplary efforts in strengthening balsa prior to its use in any structural project.

O'Neill [10] implemented balsa as hollow-core of a fiber-reinforced sandwich composite to create a short-span lightweight bridge substitute replacing short-span steel bridge for US Army. The scaled experiment using carbon-resin-epoxy shown a possibility that the full-scale bridge prototype could support the 60.000 lbs load of a fully loaded tank with under 6 inches deflection. This means that balsa, regardless of its weakness in the raw from, proved to have ability to provide higher strength to weight ratio as a composite. However, the aforementioned experiment of hollow-core balsa was applied to a straight plane. Construction of hollow core balsa in the curved surface is yet to be tested.

While O'Neill showed the usage of hollow balsa in the composite, Mohammadi \& Nairn [20] examined the usage of laminated veneer lumber (LVL) balsa as the core. The result of the experiment indicates that the LVL balsa core might improve the toughness of the composite, depends on the adhesives used. For example, the experiment revealed that polyurethane adhesives (G39) gave significant improvement. LVL might be easily bended into a curved surface. Therefore, the usage of LVL balsa core might be included into consideration.

\section{Manufacture Establishment}

\subsection{Current and projected Balsa supply in Indonesia}

Balsa is categorized as kayu lain-lain (other wood) in Indonesian Central-Bureau of Statistics due its less significant position in the current wood industry. However, as implied by online media, the position of balsa as investment interest has increased significantly. One of the companies which actively investing in balsa plantation is CV Tipeling with total plantation area $28 \mathrm{Ha}$ in 2015-2018. Data from the Branch Leader of Muhammadiyah Paseh, one of whom made a joint venture with CV Tipeling in balsa plantation, showed that this plantation was spread in Nagreg, Sukabumi, Cijapati, dan Garut. Total number of trees in the plantation is reaching 29.000 trees. Considering the fact that the harvesting cycle of balsa is around 3-5 years and the assumption that one balsa tree can produce $1,07 \mathrm{~m}^{3}$ of wood, it can be projected that there will be $31.030 \mathrm{~m}^{3}$ addition of balsa material in 2020 from this single company. This projection reveals potential of increased national balsa supply to support local industry in the near future. 


\subsection{Prototyping requirement of possible product(s)}

A multi-disciplinary expert team is required in developing intended balsa composite prototype, especially with expertise in design, structure, material, and chemistry. Environmental study of the designed manufacture is also required to avoid unwanted environmental impact. The prototype should be explored in scaled specimens and tested in full-scale model, then submitted to secure the intellectual right prior its test to the market. Strong [21] in his book Fundamentals of Composites Manufacturing: Materials, Methods, and Applications provided examples of tests and methods for composite quality control. The proper prototype should also suggest possible efficient manufacturing process of the end product and its feasible development. Another main material used in the product; the matrix and the fiber, should be chosen carefully to meet the environmental and economical standard.

\subsection{Manufacture requirements}

In manufacture scale, the requirement of machinery and tools are varied, depends on the intended end-products. From the projected intention of developing curved balsa composites, the industry will need large drying chamber for the wood (or oven), dry room storage, wood processing machine (slicer, trimmer, planner, cutter, and sander), steam room, laminating tools, chemicals, ventilating and cleaning device, finishing tools, testing tools, waste processing system, packaging, and delivery system. Digital fabrication machine such as CNC might be needed, depends on the scope of work and intended end products.

All the machinery and tools required for manufacture are available in the market. Development of custom machine or new machine altogether might not be needed. However, finding the right machine and tools depends on excellent design of the manufacture system, which should be the task of the prototyping team.

\subsection{Business model alternatives}

Considering the classification of creating balsa composites as a secondary-sector industry, the most straightforward business model is a manufacture or factory model. However, there are also another alternatives such as a 'studio' model, and a 'colab-factory' model (colab is a shorten term of collaboration or co-laboratory). 
The conventional factory model would deliver some standard panels in a massive scale and would require a distribution or a retail system to sell the end-product. This model would also require massive marketing effort in introducing the product to the market, and no small amount of start-up capital investment. On the other hand, the 'studio' model would allow the company to create customized and varied products from standardized composite module(s) in limited number of ready-stock products. Studio scale could be smaller than the factory and the end-products will be more exclusive. The third alternatives, the 'colab-factory', would require costumer participation in the process of creating the products. The 'colab-factory' main activities are creating the module or standard material and providing the means for customer to create their own end-products.

\subsection{Important factor of the establishment}

Supply of raw materials and tools is one of the most important factors in the business model, regardless which model that had been chosen from the alternatives. The efficient establishment will required access to the supplies, with less cost of the material procurement. The factory model establishment, however, will differ from the 'colab-factory' model in term of customer accessibility. In the 'colab-factory' model, the customer or the 'colab' will have to access the facility so that the location with high accessibility is crucial for the establishment. Digital collaboration might be added to the 'colab-factory' model in order to expand the scale of the business though digitalization. With this addition, the 'colab-factory' establishment does not have to be accessed physically by the customer.

\subsection{Future possibility of Indonesian native fast-grown plants}

There are several fast-grown plants used in Indonesian Vernacular Architecture. Sengon (Albizia falcate), which is used in Sundanese houses [22] has 4-10 years harvesting cycle. Sentang (Azadirachta excelsa), which is used in Acehnese houses [23] has 6-7 years harvesting cycle. Bamboo (Bambsoideae) could be harvested in 3-5 years, meanwhile Rattan (Calamae) could be harvested in 7 up to 20 years. These four examples of fastgrown plants might have or might have not been possible to be developed in a similar way of balsa. There are rooms for research and experiment in finding balsa alternative from Indonesian native plants. The research will fit in the interest of Indonesian Government to develop Indonesian wood with more added value in its end products. 


\section{Conclusion}

In conclusion, development of Balsa into a curved surface and its manufacture establishment in Indonesia is feasible from theoretical and statistical point of view. This statement is derived from three points: (1) national balsa supply is projected to be increased in 2020 , (2) the development of prototype require multidisciplinary expert team which is exist in Indonesian human-resources, and (3) manufacture establishment only required machinery which are available in the market. There are three business model alternatives: (1) the conventional factory model, (2) the studio model, and (3) the 'colab-factory' model. Chosen model will affects the establishment, the amount of capital required, and the scale of the business. The successful presence of the end-product in the market, will also open the possibility on finding balsa alternative in Indonesian native plants.

\section{References}

[1] Usop TB. Pelestarian arsitektur tradisional Dayak pada pengenalan ragam bentuk konstruksi dan teknologi tradisional Dayak di Kalimantan Tengah. Jurnal Perspektif Arsitektur Volume. 2014;9(2).

[2] Zakiah H, Octavia HC. Studi adaptasi rumah vernakular Kutai terhadap lingkungan rawan banjir di Tenggarong 2013.

[3] Sudarmin S. Kajian tipologi morfologi rumah vernakular di daerah Teratak Buluh. Jurnal Arsitektur: Arsitektur Melayu dan Lingkungan. 2015;2(1).

[4] Taal S. The limas house of Palembang. In: Schefold R, Nas PJM, Wessing R, editors. Indonesian houses vol 2: survey of vernacular architecture in Western Indonesia. 2.; 251. Leiden, The Netherlands: KITLV Press; 2008.

[5] Alimansyur M, Makmur Z, Sidin T. Arsitektur tradisional daerah Sumatera Selatan. Direktorat Jenderal Kebudayaan; 1985.

[6] Statistik produksi kehutanan. 2014. Jakarta: Badan Pusat Statistik; 2014.

[7] Charomaini, M., \& Windiasih, S. R. D. (2005). Peningkatan Daya Kecambah Benih Balsa melalui Perendaman dalam Air dan Larutan Kimiawi. Jurnal Penelitian Hutan Tanaman, 2(2), 68-73.

[8] Osei-Antwi, M., De Castro, J., Vassilopoulos, A. P., \& Keller, T. (2013). Shear mechanical characterization of balsa wood as core material of composite sandwich panels. Construction and Building Materials, 41, 231-238.

[9] Midgley, S. (2015). Balsa Industry, PNG: Market analysis and strategic development. ACIAR Balsa Market Report). ACIAR. 
[10] O’Neill, K. (2010). Feasibility Study Of Lightweight High-strength Hollow Core Balsafrp Composite Beams under Flexure.

[11] Bar, M., \& Neta, M. (2007). Visual elements of subjective preference modulate amygdala activation. Neuropsychologia, 45(10), 2191-2200.

[12] Cramer, J., \& Browning, W. (2008). Transforming building practices through biophilic design. Biophilic design. Hoboken: Wiley, 335, 346.

[13] Iwamoto, L. (2013). Digital fabrications: architectural and material techniques: Princeton Architectural Press.

[14] Adriaenssens, S., Block, P., Veenendaal, D., \& Williams, C. (2014). Shell Structures for Architecture: Form Finding and Optimization

[15] García, V. A., \& Díaz, J. A. (2013). Great light spans. Geometry and simple structural behaviour. 2nd half of the book

[16] Kuijvenhoven, M. (2009). A Design Method for Timber Grid Shell.

[17] Keller, T., Rothe, J., De Castro, J., \& Osei-Antwi, M. (2013). GFRP-balsa sandwich bridge deck: Concept, design, and experimental validation. Journal of Composites for Construction, 18(2), 04013043.

[18] Astasari, A., Sutikno, S., \& Wijanarko, W. (2017). Bending and Torsional Characteristics of Carbon Fiber and Balsa Wood Sandwich Composite. IPTEK Journal of Proceedings Series(2), 5-9.

[19] Alex, T., Winarni, B., Kusuma, I. W., Arung, E. T., \& Budiarso, E. (2017). The clay nanoparticle impregnation for increasing the strength and quality of sengon (Paraserianthes falcataria) and white meranti (Shorea bracteolata) timber. NUSANTARA BIOSCIENCE, 9(1), 107-110.

[20] Mohammadi, M. S. \& Nairn, J. A. (2017). Balsa sandwich composite fracture study: Comparison of laminated to solid balsa core materials and debonding from thick balsa core materials. Composites Part B: Engineering, 122, 165-172.

[21] Strong, A. B. (2008). Fundamentals of composites manufacturing: materials, methods and applications. Society of Manufacturing Engineers.

[22] Riany M, Rachmadi Y, Sambira IY, Muharam AT, Taufik RM. Kajian aspek kosmologisimbolisme pada arsitektur rumah tinggal vernakular di Kampung Naga. REKA KARSA. 2014;2(4).

[23] Mirsa, R. (2013). Rumoh Aceh: Graha Ilmu. 